\title{
Nitrous oxide emissions from fertilized and unfertilized grasslands on peat soil
}

\author{
C. L. van Beek $\cdot$ M. Pleijter • P. J. Kuikman
}

Received: 2 July 2010/Accepted: 4 October 2010/Published online: 20 October 2010

(C) The Author(s) 2010. This article is published with open access at Springerlink.com

\begin{abstract}
Emissions of nitrous oxide $\left(\mathrm{N}_{2} \mathrm{O}\right)$ from managed and grazed grasslands on peat soils are amongst the highest emissions in the world per unit of surface of agriculturally managed soil. According to the IPCC methodology, the direct $\mathrm{N}_{2} \mathrm{O}$ emissions from managed organic soils is the sum of $\mathrm{N}_{2} \mathrm{O}$ emissions derived from $\mathrm{N}$ input, including fertilizers, urine and dung of grazing cattle, and a constant 'background' $\mathrm{N}_{2} \mathrm{O}$ emission from decomposition of organic matter that depends on agro-climatic zone. In this paper we questioned the constant nature of this background emission from peat soils by monitoring $\mathrm{N}_{2} \mathrm{O}$ emissions, groundwater levels, $\mathrm{N}$ inputs and soil $\mathrm{NO}_{3}{ }^{-}-\mathrm{N}$ contents from 4 grazed and fertilized grassland fields on managed organic peat soil. Two fields had a relatively low groundwater level ('dry' fields) and two fields had a relatively high groundwater level ('wet' fields). To measure the background $\mathrm{N}_{2} \mathrm{O}$ emission, unfertilized sub-plots were installed in each field. Measurements were performed monthly and after selected management events for 2 years (2008-2009). On the managed fields average cumulative emission equaled $21 \pm 2 \mathrm{~kg} \mathrm{~N}^{-1} \mathrm{y}^{-1}$ for the 'dry' fields and $14 \pm 3 \mathrm{~kg} \mathrm{~N} \mathrm{ha}^{-1} \mathrm{y}^{-1}$ for the 'wet' fields. On the unfertilized sub-plots emissions equaled $4 \pm 0.6 \mathrm{~kg} \mathrm{~N} \mathrm{ha}^{-1} \mathrm{y}^{-1}$ for the 'dry' fields
\end{abstract}

C. L. van Beek $(\bowtie) \cdot$ M. Pleijter · P. J. Kuikman Alterra, Wageningen UR, P.O. Box 47, 6700 AA Wageningen, The Netherlands

e-mail: christy.vanbeek@wur.nl and $1 \pm 0.7 \mathrm{~kg} \mathrm{~N} \mathrm{ha}^{-1} \mathrm{y}^{-1}$ for the 'wet' fields, which is below the currently used estimates. Background emissions were closely correlated with groundwater level $\left(R^{2}=0.73\right)$ and accounted for approximately $22 \%$ of the cumulative $\mathrm{N}_{2} \mathrm{O}$ emission for the dry fields and for approximately $10 \%$ of the cumulative $\mathrm{N}_{2} \mathrm{O}$ emissions from the wet fields. The results of this study demonstrate that the accuracy of estimating direct $\mathrm{N}_{2} \mathrm{O}$ emissions from peat soils can be improved by approximately $20 \%$ by applying a background emission of $\mathrm{N}_{2} \mathrm{O}$ that depends on annual average groundwater level rather than applying a constant value.

Keywords Nitrate $\cdot$ Groundwater level $\cdot$ Cultivated organic soil · Peat · Grassland · Seasonal effects · Farm management $\cdot$ Mitigation

\section{Introduction}

Most nitrous oxide $\left(\mathrm{N}_{2} \mathrm{O}\right)$ is emitted from agricultural soils, especially after application of mineral and organic nitrogen (N) fertilizers (Mosier et al. 1998). The emission of $\mathrm{N}_{2} \mathrm{O}$ contributes to global warming and stratospheric ozone destruction (Wuebbles 2009). Following the Intergovernmental Panel on Climate Change (IPCC) guidelines to calculate the emission of $\mathrm{N}_{2} \mathrm{O}$ from managed organic (i.e. peat) soils one 
discriminates between a constant emission due to the cultivation and drainage of peat soil and a variable emission depending on the types and amounts of $\mathrm{N}$ inputs (de Klein et al. 2006). The first can be considered as a 'background' or reference $\mathrm{N}_{2} \mathrm{O}$ emission for cultivation of soils including drainage and the latter as a net emission for agricultural management induced emission of $\mathrm{N}_{2} \mathrm{O}$. The IPCC distinguishes several levels of detail for reporting. These levels of detail are called Tiers and go from large spatial units (Tier 1) to smaller spatial units (Tiers 2 and 3). For the Netherlands, the IPCC Tier 1 methodology applies a background emissions of $8 \mathrm{~kg} \mathrm{~N}-\mathrm{N}_{2} \mathrm{O}$ ha $^{-1} \mathrm{y}^{1}$, but this figure is based on limited experimental data (Couwenberg 2009). For the national reporting obligations The Netherlands uses a Tier 2 approach in which the calculated averaged background emission for peat soil is $4.7 \mathrm{~kg} \mathrm{~N} \mathrm{ha}^{-1} \mathrm{y}^{-1}$ (Protocol 8132 Direct emissions from agriculture, van der Hoek et al. 2007). Both approaches consider this background emission as a constant value.

To halt, or slow down, $\mathrm{N}_{2} \mathrm{O}$ emissions there is a demand for effective $\mathrm{N}_{2} \mathrm{O}$ mitigation measures. The development of such measures is complicated by high spatial and temporal variability and a still limited understanding of driving forces of $\mathrm{N}_{2} \mathrm{O}$ emissions at field and regional scales which may limit the specificity and effectiveness of defined measures. At small scales, the emission of $\mathrm{N}_{2} \mathrm{O}$ is favoured by simultaneous occurrence of anaerobic conditions, ample availability of $\mathrm{NO}_{3}{ }^{-}$and of organic matter (Tiedje et al. 1984). Consequently, high emission peaks can occur directly following fertilizer application (Williams et al. 1999), especially under humid and organic carbon rich conditions. These favourable conditions for $\mathrm{N}_{2} \mathrm{O}$ emissions are commonly found in pastures on peat soils in The Netherlands and consequently these soils are major contributors to the national $\mathrm{N}_{2} \mathrm{O}$ emission (Velthof and Oenema 1995). In these managed organic soils, the main manageable control factors for $\mathrm{N}_{2} \mathrm{O}$ emission are fertilizer applications (governing the $\mathrm{NO}_{3}{ }^{-}$contents in the soil) and groundwater level (governing the anaerobicity and mineralization rate in the soil) as metabolizable $\mathrm{C}$ is generally widely available throughout the soil profile (van Beek et al. 2004).

In the National Inventory Report of The Netherlands about 223,000 ha is classified as managed peat soil (van der Hoek et al. 2007) and these soils typically receive $300-500 \mathrm{~kg} \mathrm{~N}^{-1} \mathrm{y}^{-1}$ (van Beek et al. 2010) mainly as Calcium Ammonium Nitrate (CAN) fertilizer and cattle manure. These managed peat soils have a distinct water management with shallow, i.e. nearly ponded, groundwater levels in winter and somewhat deeper, i.e. up to one meter in the middle of fields, groundwater levels in summer. At present, the water table is managed and adjusted towards agricultural management. This requires a minimum bearing capacity for equipment and cattle and hence extended drainage during the growing season although this enhances mineralization and subsidence of the soil (Verhoeven and Setter 2010; de Haan et al. 2006). In winter, groundwater levels rise and may reach the soil surface. This water table management is currently under debate, because of the ongoing subsidence of the soil and associated high emissions of $\mathrm{CO}_{2}$, yet the majority is still managed as described above.

In this study the background emission was defined as the $\mathrm{N}_{2} \mathrm{O}$ emissions obtained from unfertilized and mown fields. Net direct $\mathrm{N}_{2} \mathrm{O}$ emission was defined as the total emission minus the background emission. The net emissions was considered a measure of agricultural management induced $\mathrm{N}_{2} \mathrm{O}$ emissions. The background emission was considered to be primarily governed by soil management via drainage. Following the good practice guidance approach of the IPCC at Tier 1 and Tier 2 level, for calculation of the background emission a constant value for the emission should be used in each climatic zone. However, previous experimental and simulation studies on $\mathrm{N}_{2} \mathrm{O}$ emission from managed peat soil point towards increasing $\mathrm{N}_{2} \mathrm{O}$ emissions with increasing $\mathrm{N}$ input rates and groundwater levels (Schrier-Uijl et al. 2010; Velthof and Oenema 1995; Velthof et al. 1996a; Langeveld et al. 1997), which indicates that in fact the background emission may be related to groundwater level. Moreover, considering that groundwater level are deepest and $\mathrm{N}$ inputs are highest in summer, a seasonal fluctuation with relatively high net and background emissions during summer is expected. In this study, the above mentioned hypotheses were tested with experimental data on $\mathrm{N}_{2} \mathrm{O}$ emissions from four fields with two different groundwater management regimes in the Western peat land area of The Netherlands. This study is a continuation and extension of the study described by van Beek et al. (2010). 
In van Beek et al. (2010) total $\mathrm{N}_{2} \mathrm{O}$ emissions per unit of $\mathrm{N}$ input were positively related to groundwater level, but they could not discriminate between effects induced by groundwater level and effects induced by fertilization. In 2008 the experimental design was extended with the installation of unfertilized and mown sub-plots in order to quantify background $\mathrm{N}_{2} \mathrm{O}$ emissions.

\section{Materials and methods}

Site description

Measurements were performed at experimental dairy farm 'Zegveld' located in the Western part of the Netherlands $\left(52^{\circ} 26^{\prime} \mathrm{N}, 4^{\circ} 48^{\prime} \mathrm{E}\right)$. Four fields were selected for intensive monitoring, which had a mean groundwater level of $40 \mathrm{~cm}$ below soil surface ('wet' fields) and $55 \mathrm{~cm}$ below soil surface ('dry' fields). The soil was classified as Terric Histosol according to Food and Agriculture Organization (FAO) classification. Briefly, fields were drained by tile drains, grazed and fertilized according to common agricultural practices and received about $370 \mathrm{~kg} \mathrm{~N} \mathrm{ha}^{-1} \mathrm{y}^{-1}$. During each sampling event 96 fluxes, equally distributed over the managed fields, were measured. Detailed descriptions of the experimental design, measurements and field management of the managed fields are provided in van Beek et al. (2010). Nitrous oxide fluxes have been monitored in fields 2 and 13 since 2005. In 2008 two more fields were added to the experimental design in order to validate conclusions. Also, in 2008 subplots were installed in all 4 fields, which were fenced off and did not receive any $\mathrm{N}$ addition through fertilizer applications and grazing, but were mown according to the managed fields. The subplots served to quantify the background $\mathrm{N}_{2} \mathrm{O}$ emission from soil and are called reference fields from hereon. Nitrous oxide emissions from the reference fields were measured on the same dates as the managed fields and per sampling event $\mathrm{N}_{2} \mathrm{O}$ measurements were performed on 6 randomly selected locations in the reference fields. Some general characteristics of the fields are provided in Table 1.

\section{Measurements}

Nitrous oxide flux measurements were performed once a month (regular sampling scheme) and after three selected management activities ('events'): two manure applications and one fertilizer application. Measurements were performed at approximately 1, 7, 14, 21 and 28 days after the selected events. In total 40 sampling events were performed in 2 years (2008-2009). Nitrous oxide fluxes were measured as described in van Beek et al. (2010). All management activities were recorded and sometimes events overlapped (e.g. fertilizer application and grazing). Mineral soil $\mathrm{N}\left(\mathrm{NO}_{3}{ }^{-}\right.$and $\left.\mathrm{NH}_{4}{ }^{+}\right)$contents were measured from February 2007 onwards by Segmented Flow Analysis (SFA) for the managed fields 2 and 13 and from Spring 2009 onwards also for the

Table 1 Main characteristics of selected fields, average results for the years 2008-2009

\begin{tabular}{llllllr}
\hline Field code & Year & $\begin{array}{l}\text { Drainage } \\
\text { condition }\end{array}$ & $\begin{array}{l}\text { Annual average groundwater } \\
\text { level (cm below soil surface) }\end{array}$ & $\begin{array}{l}\mathrm{N} \text { input } \\
\left(\mathrm{kg} \mathrm{ha}^{-1} \mathrm{y}^{-1}\right)\end{array}$ & $\begin{array}{l}\mathrm{NO}_{3}{ }^{-}-\mathrm{N} \pm \mathrm{sd} \\
\left(\mathrm{mg} \mathrm{kg}^{-1}\right)^{\mathrm{a}, \mathrm{b}}\end{array}$ & $\begin{array}{l}\mathrm{N}_{2} \mathrm{O}-\mathrm{N} \text { emission } \pm \mathrm{sd} \\
\left(\mathrm{kg} \mathrm{N} \mathrm{ha}^{-1} \mathrm{y}^{-1}\right)\end{array}$ \\
\hline 2 & 2008 & Dry & 38 & 507 & $27 \pm 23$ & $33.4 \pm 13.0(7.6 \pm 8.4)$ \\
2 & 2009 & Dry & 45 & 502 & $50 \pm 35(30 \pm 20)$ & $27.3 \pm 16.2(6.9 \pm 4.0)$ \\
3 & 2008 & Dry & 34 & 321 & $12.8 \pm 3.0(2.9 \pm 0.9)$ \\
3 & 2009 & Dry & 41 & 557 & $11.1 \pm 8.1(3.4 \pm 1.5)$ \\
11 & 2008 & Wet & 14 & 481 & & $2.7 \pm 1.9(1.0 \pm 0.4)$ \\
11 & 2009 & Wet & 13 & 506 & & $6.4 \pm 8.9(0.2 \pm 0.3)$ \\
13 & 2008 & Wet & 19 & 353 & $14 \pm 8$ & $27.4 \pm 33.6(1.0 \pm 0.3)$ \\
13 & 2009 & Wet & 24 & 395 & $16 \pm 12(9 \pm 3)$ & $20.1 \pm 23.8(2.0 \pm 0.7)$ \\
\hline
\end{tabular}

In brackets results of reference fields (where applicable)

a Nitrate analyses were omitted for fields 3 and 13

b $\quad 0-20 \mathrm{~cm}$ below soil surface 
Table 2 Measurements performed per field between the years 2005-2009

\begin{tabular}{llllll}
\hline Field code & 2005 & 2006 & 2007 & 2008 & 2009 \\
\hline 2 & $\mathrm{~N}_{2} \mathrm{O}, \mathrm{GWL}$ & $\mathrm{N}_{2} \mathrm{O}, \mathrm{GWL}$ & $\mathrm{N}_{2} \mathrm{O}, \mathrm{GWL}, \mathrm{NO}_{3}^{-}$ & $\mathrm{N}_{2} \mathrm{O}, \mathrm{GWL}, \mathrm{NO}_{3}^{-{ }^{-}}$ & $\mathrm{N}_{2} \mathrm{O}, \mathrm{GWL}, \mathrm{NO}_{3}^{-}$ \\
3 & & & $\mathrm{~N}_{2} \mathrm{O}, \mathrm{GWL}$ & $\mathrm{N}_{2} \mathrm{O}, \mathrm{GWL}$ \\
11 & & $\mathrm{~N}_{2} \mathrm{O}, \mathrm{GWL}$ & $\mathrm{N}_{2} \mathrm{O}, \mathrm{GWL}$ \\
13 & $\mathrm{~N}_{2} \mathrm{O}, \mathrm{GWL}$ & $\mathrm{N}_{2} \mathrm{O}, \mathrm{GWL}$ & $\mathrm{N}_{2} \mathrm{O}, \mathrm{GWL}, \mathrm{NO}_{3}^{-}$ & $\mathrm{N}_{2} \mathrm{O}, \mathrm{GWL}, \mathrm{NO}_{3}{ }^{-}$ & $\mathrm{N}_{2} \mathrm{O}, G W L, \mathrm{NO}_{3}^{-}$ \\
\hline
\end{tabular}

Italic parameters indicate inclusion of reference fields in measurements

reference fields. Fields 3 and 11 were omitted from $\mathrm{NO}_{3}{ }^{-}$analyses due to limitations is sampling capacity. Soil samples $(0-20 \mathrm{~cm}$ and $20-40 \mathrm{~cm}$ below soil surface) were taken from a regular grid for the managed fields and as mix samples $(n=6)$ from the reference fields. Groundwater levels were measured semi-continuously using groundwater sensors in fields 2 and 13 and every 14 days using groundwater probes in fields 3 and 11. For this paper we used the time window of January 2008-November 2009 during which most measurements were performed simultaneously on all fields (Table 2).

Data analysis

Net $\mathrm{N}_{2} \mathrm{O}$ emissions were calculated by subtracting the $\mathrm{N}_{2} \mathrm{O}$ fluxes from the reference fields from the managed fields on a daily basis. Summer net emissions were defined as the cumulative net emission between April 1 and September 30, 2008. Winter net emission referred to the emissions in the adjacent winter of October 1, 2008 and March 31, 2009. Cumulative $\mathrm{N}_{2} \mathrm{O}$ emissions were calculated by linear interpolation between sampling points. Nitrogen inputs included fertilizer application (CAN), manure application and droppings of grazing cattle. To calculate gross manure applications to $\mathrm{kg} \mathrm{N}$ per hectare we used a $\mathrm{N}$ content of manure of $0.56 \mathrm{~kg} \mathrm{~N} \mathrm{~m}^{-3}$ and an $\mathrm{N}$ content of cattle droppings of $0.48 \mathrm{~kg} \mathrm{~N} \operatorname{cow}^{-1} \mathrm{~d}^{-1}$ (van Beek et al. 2010). Cumulative annual net emissions and cumulative annual background emissions were related to total annual $\mathrm{N}$ inputs and mean annual groundwater levels, respectively, using linear regression analyses.

\section{Results}

Groundwater levels, $\mathrm{N}$ inputs and soil $\mathrm{NO}_{3}{ }^{-}$ contents

Groundwater levels ranged between 0 and $70 \mathrm{~cm}$ below soil surface, with relatively deep groundwater levels in summer and relatively shallow groundwater levels in winter. Sometimes groundwater levels reached the surface and puddles occurred (Fig. 1).
Fig. 1 Groundwater level and soil $\mathrm{NO}_{3}{ }^{-}-\mathrm{N}$ contents for dry (2) and wet (13) fields. Closed symbols refer to managed fields, open symbols refer to reference fields

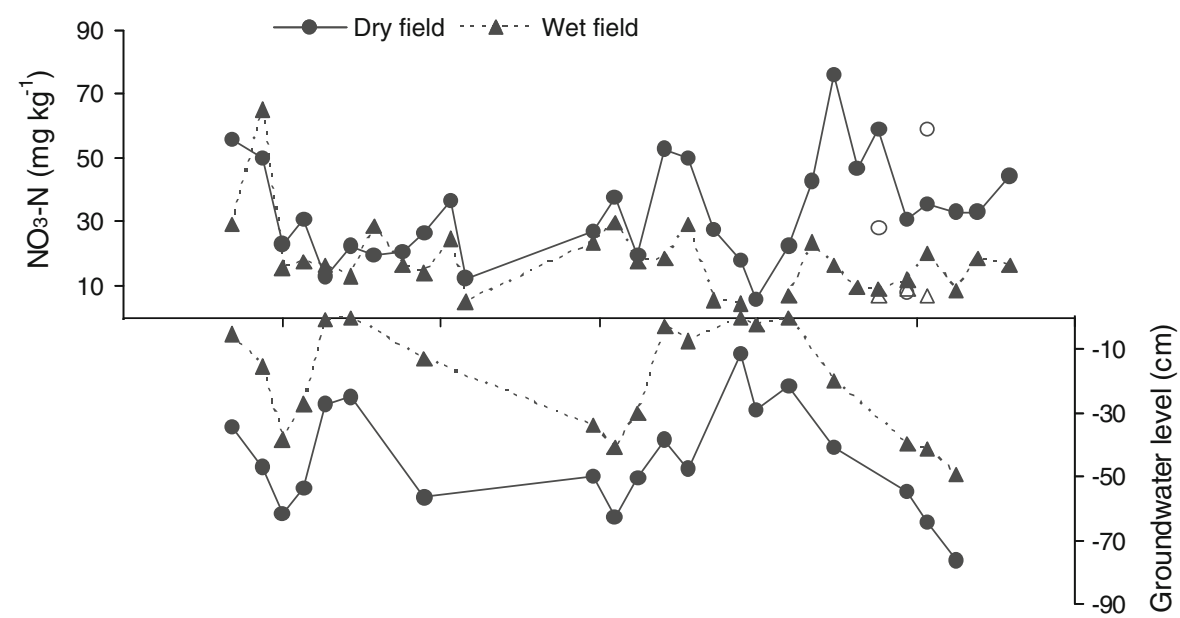

10-10-2006 28-04-2007 14-11-2007 01-06-2008 18-12-2008 06-07-2009 22-01-2010 
In general, the wet fields had more shallow groundwater levels compared to the dry field (Table 1). Average soil $\mathrm{NO}_{3}{ }^{-}$contents fluctuated between 4 and $76 \mathrm{mg} \mathrm{kg}^{-1} \mathrm{NO}_{3}{ }^{-}-\mathrm{N}$. Soil $\mathrm{NO}_{3}{ }^{-}$contents of the dry fields significantly exceeded $\mathrm{NO}_{3}{ }^{-}$contents of the wet fields $(p<0.0001)$. Generally, soil $\mathrm{NO}_{3}{ }^{-}$contents of the managed fields exceeded those of the reference fields, but exceptions occurred (Fig. 1). Soil $\mathrm{NH}_{4}{ }^{+}-\mathrm{N}$ contents varied considerably between 1.0 and $258.0 \mathrm{mg} \mathrm{kg}^{-1}$ and there was no clear distinction between the wet and dry fields (not shown). Total $\mathrm{N}$ inputs through management practices ranged from $321 \mathrm{~kg} \mathrm{~N} \mathrm{ha}^{-1} \mathrm{y}^{-1}$ for wet field 13 in 2006 to $557 \mathrm{~kg} \mathrm{~N} \mathrm{ha}^{-1} \mathrm{y}^{-1}$ for dry field 2 in 2008. The majority of these inputs were caused by droppings of grazing cattle (van Beek et al. 2010). In general the wet fields received less $\mathrm{N}$ inputs (Table 1).

\section{$\mathrm{N}_{2} \mathrm{O}$ emissions}

Figure 2 shows the course of the $\mathrm{N}_{2} \mathrm{O}-\mathrm{N}$ fluxes in time for all fields and for the reference fields within these fields. Fluxes were highly variable in time and showed distinct peaks. For more than $95 \%$ of the sampling days the $\mathrm{N}_{2} \mathrm{O}$ emissions from the managed fields exceeded the emissions from the reference fields. The net emission of field 13 was largely governed by the peak in August 2008. This peak was the result of an overall relatively high emission on that day in field 13, with 3 locations having an emission of more than $1 \mathrm{~kg} \mathrm{~N}-\mathrm{N}_{2} \mathrm{O} \mathrm{ha}^{-1} \mathrm{~d}^{-1}$. The peak was probably caused by the combination of humid conditions and the presence of cattle in field 13 during the August 2008 sampling event. Apart from this peak, the net fluxes from the dry fields in general exceeded the net fluxes from the wet fields. During winter the temporal variability in net fluxes seemed to be lower compared to summer, but this could not be considered as a consistent pattern.

Annual cumulative emissions from the managed fields ranged from $3 \mathrm{~kg} \mathrm{~N} \mathrm{ha}^{-1} \mathrm{y}^{-1}$ for wet field 11 in 2008 to $33 \mathrm{~kg} \mathrm{~N} \mathrm{ha}^{-1} \mathrm{y}^{-1}$ for dry field 2 in 2008 , but differences between fields with comparable drainage were high (Table 1). About $30 \%$ of the annual cumulative emissions occurred during summer for the dry fields, whereas for the wet fields about $85 \%$ of the total annual $\mathrm{N}_{2} \mathrm{O}$ emission occurred during summer (Fig. 3). Background emissions accounted for about $25 \%$ of the cumulative summer emissions
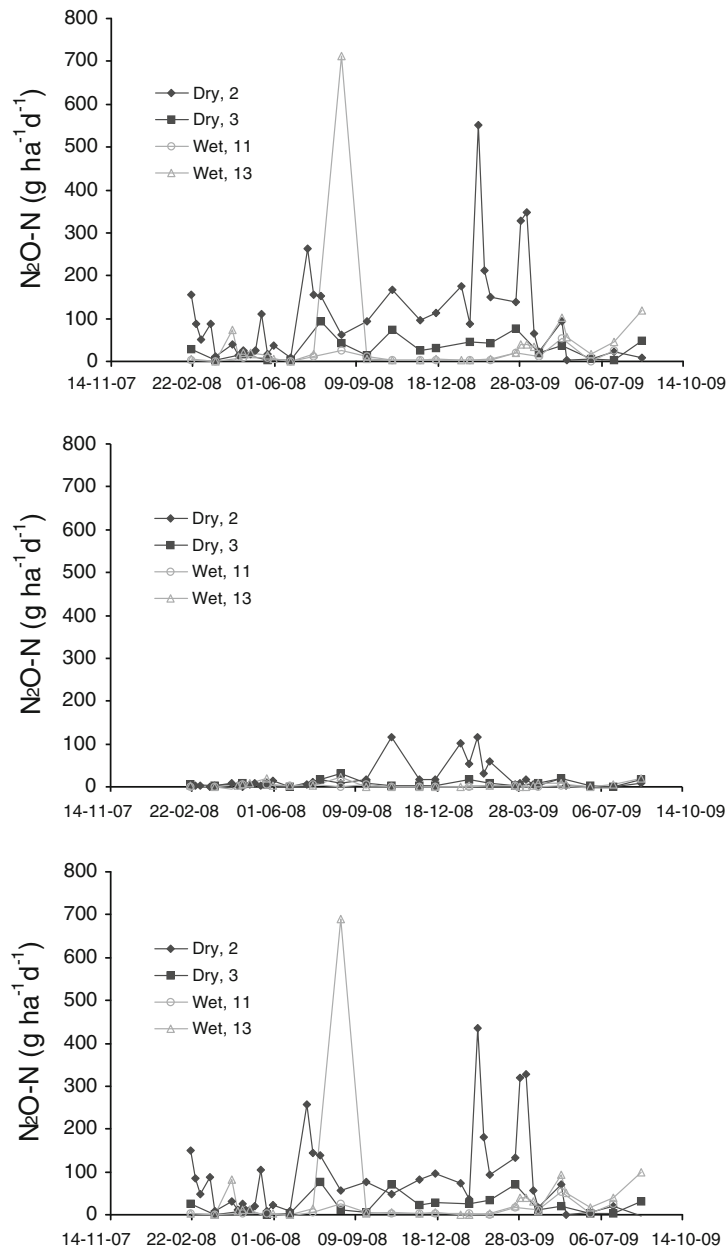

Fig. 2 Average total $\mathrm{N}_{2} \mathrm{O}-\mathrm{N}$ total fluxes (top), reference fluxes (middle) and net fluxes (below) for all fields

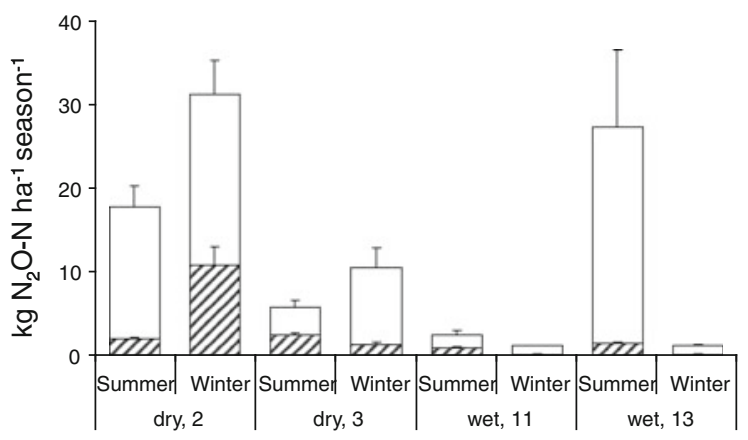

Fig. 3 Cumulative emissions for managed fields (open bars) and for reference fields (dashed bars) for summer 2008 and the adjacent winter of 2008-2009. Error bars show standard errors

for all fields. In winter, the reference fields accounted for $24 \%$ of the total emissions for the dry fields and for $17 \%$ of the total emissions for the wet fields (Fig. 3). 
Estimating $\mathrm{N}_{2} \mathrm{O}$ emissions from managed peat lands

Mean annual groundwater levels explained $73 \%$ of the cumulative annual background emissions and showed a positive relation with background $\mathrm{N}_{2} \mathrm{O}$ emissions (Fig. 4). The cumulative annual net emissions, however, could not be related to total annual $\mathrm{N}$ inputs (significance $F>0.8$ ). Neither was the relative cumulative annual net $\mathrm{N}_{2} \mathrm{O}$ emission (i.e. net $\mathrm{N}_{2} \mathrm{O}$ emission/ $\mathrm{N}$ input) related to groundwater level (significance $F>0.4$ ).

\section{Discussion}

Background emissions from drained organic soils

Velthof et al. (1996b) reported background emissions from peat soils in The Netherlands for the years 1992-1994 of $5.3 \pm 5.2 \mathrm{~kg} \mathrm{~N}-\mathrm{N}_{2} \mathrm{O}$ ha $^{-1} \mathrm{y}^{-1}$, based on measurements at the same site as used in the present study. These results show reasonable agreement with our results with an average background emission of $3.2 \pm 2.9 \mathrm{~kg} \mathrm{~N}-\mathrm{N}_{2} \mathrm{O} \mathrm{ha}^{-1} \mathrm{y}^{-1}$ (Table 1). Moreover, from March till November 1992 Velthof and Oenema (1995) measured $\mathrm{N}_{2} \mathrm{O}$ emissions from unfertilized, fertilized + mown and fertilized + grazed fields and hence could discriminate the management induced emission from fertilizer-derived emissions and from grazing-derived emissions. This experiment showed that for peat soils about $40 \%$ of the management induced $\mathrm{N}_{2} \mathrm{O}$ emissions was derived from fertilizer and

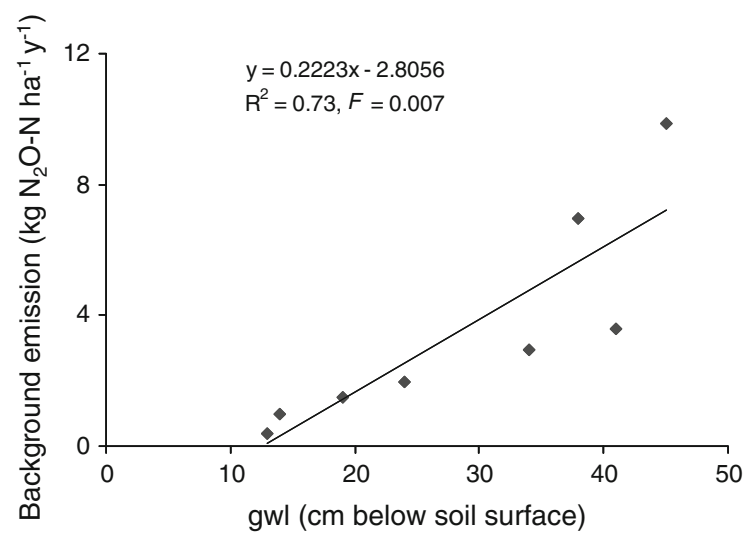

Fig. 4 Mean annual groundwater level and cumulative annual background emission. Solid line shows linear regression the remainder $60 \%$ from cattle droppings through grazing.

For the national reporting obligations towards the UNFCCC The Netherlands applies a Tier 2 method with a calculated background emission factor value for all drained organic soils of $4.7 \mathrm{~kg} \mathrm{~N}-\mathrm{N}_{2} \mathrm{O} \mathrm{ha}^{-1} \mathrm{y}^{-1}$ (Protocol 8132 Direct emissions from agriculture, van der Hoek et al. 2007). At Tier 1 level the IPCC derived a constant value of $8 \mathrm{~kg} \mathrm{~N}-\mathrm{N}_{2} \mathrm{O} \mathrm{ha}^{-1} \mathrm{y}^{-1}$. In our study the background emissions ranged between 0.2 and $7.6 \mathrm{~kg} \mathrm{~N}-\mathrm{N}_{2} \mathrm{O} \mathrm{ha} \mathrm{ha}^{-1} \mathrm{y}^{-1}$ for wet and dry soils, respectively (Table 1). These results indicate that the IPCC Good Practice Guidance overestimates the background emissions for relatively wet soils and that the Tier 2 approach of the Netherlands predominantly refers to intensive drainage, i.e. relatively dry fields. In organic soils the background emission reflects $\mathrm{N}_{2} \mathrm{O}$ release through drainage and consequent mineralization of organic matter and meteorological conditions like precipitation and temperature. Based on these factors a seasonal trend in background $\mathrm{N}_{2} \mathrm{O}$ emissions was expected. Indeed, summer background emissions exceeded winter background emissions by almost a factor 5 for all fields, except field 2. Just prior to the installation of the unfertilized sub-plots (October 2008) field 2 was grazed. Grazing in late autumn is unusual and has probably led to divergent results in the sub-plot of field 2. However, as we can not state this argument causally, we did not omit this subplot from further assessment, but examined the results from this sub-plot with caution.

\section{Seasonal trends}

The net emission of $\mathrm{N}_{2} \mathrm{O}$ was corrected for the reference emissions and hence does in principle exclusively reflect the effects of agricultural field management. However, even in winter in the absence of any field management, considerable differences between net emissions and background emissions persisted, as did soil $\mathrm{NO}_{3}{ }^{-}$contents (Figs. 1 and 2). Apparently, impact of management does persist in the soil for considerable lengths of time. As a consequence, measures that aim to prevent hot-spot events by delaying e.g. fertilizer application (Jones et al. 2005; Schils et al. 2006) may in fact not prevent, but rather postpone and/or dilute the emission over time. For the dry fields total emissions were higher in winter compared to summer, of which the majority 
was caused by the net emission (Fig. 3). Most likely this was caused by management induced increased $\mathrm{NO}_{3}{ }^{-}$concentration in the topsoil that could be denitrified when anaerobicity occurred, along with rising groundwater levels. Indeed, $\mathrm{NO}_{3}{ }^{-}-\mathrm{N}$ contents of the topsoil were higher in the dry fields compared to the wet fields (Table 1). Van Beek et al. (2004) demonstrated that the most active zone of denitrification of a nearby peat area was found $20-30 \mathrm{~cm}$ above the level of the groundwater table. They showed that with rising ground water levels not the extend, but the location and depth of denitrification changed. For $\mathrm{N}_{2} \mathrm{O}$ emission, denitrification is an important process, but during its way from the production site in the subsoil to the atmosphere, considerable amounts of $\mathrm{N}_{2} \mathrm{O}$ can and will be reduced to $\mathrm{N}_{2}$ (van Groenigen et al. 2005a). This may explain our findings as in winter groundwater levels are higher and consequently the vertical distance between the formation and emission of $\mathrm{N}_{2} \mathrm{O}$ are less than in summer. Nevertheless, our observation of relatively high winter $\mathrm{N}_{2} \mathrm{O}$ emissions contrasts with the results reported by Velthof et al. (1996b). They reported relatively low winter emission for the same site, but for different years notably March 1992 to March 1994. These winters were somewhat colder than the winters covered in the present study (mean winter temperature of $10.1^{\circ} \mathrm{C}$ and $10.6^{\circ} \mathrm{C}$, respectively) and with less frost. The lower winter temperatures in combination with less frost periods in the study of Velthof et al. (1996b) probably explain the deviation in results with our study.

\section{Comparisons of fields}

The dry and wet fields were managed reasonably similarly, as considered by the farmers. Yet, deviations between $\mathrm{N}$ inputs could be considerable (Table 1), which was mainly caused by differences in number and periods of grazing cattle (van Beek et al. 2010). Although this was not intentional, the variation in $\mathrm{N}$ inputs allows to assess the effects of $\mathrm{N}$ inputs for fields with similar groundwater level for similar meteorological conditions (i.e. similar years). It then appears (Table 1) that only for the dry fields (fields 2 and 3 ) in 2008 a positive relation between $\mathrm{N}$ inputs and $\mathrm{N}_{2} \mathrm{O}$ emission was observed. For the other drainage-year combinations, negative relations were found, i.e. $\mathrm{N}_{2} \mathrm{O}$ emissions decreased with increasing $\mathrm{N}$ inputs
(Table 1). The variability in response of $\mathrm{N}_{2} \mathrm{O}$ emissions to changes in $\mathrm{N}$ inputs was most likely caused by differences between fields. Notably, although the fields looked similar, field 3 was a little bit more convex compared to field 2 and hence mineralization may have been lower in field 3. In field 13 there was a small gulley, which was dry for most of the time, but may explain the differences in fluxes. Reducing $\mathrm{N}$ inputs is generally considered as an effective method to reduce net $\mathrm{N}_{2} \mathrm{O}$ emissions (Zheng et al. 2000; Mosier et al. 1996) and is also supported by our findings when all fields are taken together (van Beek et al. 2010). However, results on individual fields for certain years may deviate from this generality and conditions that may appear comparable at first sight may at the end have considerably different emission and in fact can result in 13-fold differences in annual $\mathrm{N}_{2} \mathrm{O}-\mathrm{N}$ emissions (summer average emissions of fields 11 and 13, Fig. 3).

\section{Variability}

During one sampling event about $25 \%$ of the cumulative annual emission was achieved for the dry fields, and almost half of the total cumulative annual emission (49\%) for the wet fields (Fig. 2). This observation has important consequences for estimating annual emission and confirms the importance of frequent samplings (Parkin 2008). Also, van Beek et al. (2009) demonstrated with the current dataset that spatial and temporal variability were about equal, but differed largely between the drainage conditions. In general, temporal and spatial variabilities, expressed as coefficients of variation, equaled $50 \%$ for the dry fields and approximately $110 \%$ for the wet fields. At present there is a tendency towards raising groundwater levels in peat land areas in The Netherlands to halt or slow down subsidence of the soil and prevent $\mathrm{CO}_{2}$ emission. According to our results and the results of van Beek et al. (2009) this would also result in (1) lower $\mathrm{N}_{2} \mathrm{O}-\mathrm{N}$ emissions, (2) increased spatial and temporal variability and (3) increased effects of field management on $\mathrm{N}_{2} \mathrm{O}$ emission.

Estimating $\mathrm{N}_{2} \mathrm{O}$ emissions from managed peat lands

In van Beek et al. (2010) a relation between annual relative $\mathrm{N}_{2} \mathrm{O}$ emission (i.e. $\mathrm{N}_{2} \mathrm{O}$ emission/ $\mathrm{N}$ input) 
versus mean annual groundwater level was presented. This relation explained $74 \%$ of the variation for 10 fields on the current dairy farm, distributed over different years. In van Beek et al. (2010) only total $\mathrm{N}_{2} \mathrm{O}$ emissions were measured. With the current dataset a discrimination between net $\mathrm{N}_{2} \mathrm{O}$ emissions and background $\mathrm{N}_{2} \mathrm{O}$ emissions was made and the hypothesis that the first set was mainly driven by $\mathrm{N}$ inputs and the last set mainly by groundwater level, appeared to be valid for the background $\mathrm{N}_{2} \mathrm{O}$ emission (Fig. 4), but could not be confirmed for the net $\mathrm{N}_{2} \mathrm{O}$ emission. Apparently, for the net $\mathrm{N}_{2} \mathrm{O}$ emission small scale heterogeneity caused by urine patches and trampling (van Groenigen et al. 2005b) scattered the relation between $\mathrm{N}$ input and net emissions. Moreover, for the background emissions we used the annual average groundwater level, which is generally known by water management authorities. A more dynamic approach, e.g. using average highest and average lowest groundwater levels, or seasonal average values, may further improve the relation, but may impede implementation of the approach suggested from this study in e.g. Tier 2 approaches for official reporting of greenhouse gas emissions towards the UNFCCC, due to unavailability of accurate data.

\section{Conclusions}

At present, official methods to estimate $\mathrm{N}_{2} \mathrm{O}$ emission from grazed grasslands on peat soil use a constant value for the calculation of the so called background emission rate of $\mathrm{N}_{2} \mathrm{O}$. This study shows that the background emission of intensively managed grasslands on peat soils is lower than the estimates currently used in official reports. Moreover, the background emission was strongly related to groundwater level and can be estimated with reasonable accuracy using mean annual groundwater levels. Considering that the background emission accounted for approximately $22 \%$ of the total emission for the dry fields and for approximately $10 \%$ of the total emission from the wet fields, we argue to implement a variable value to calculate the background emission of $\mathrm{N}_{2} \mathrm{O}$ in UNFCCC reporting and estimation methodologies, once our findings are confirmed for other peat soils.
Open Access This article is distributed under the terms of the Creative Commons Attribution Noncommercial License which permits any noncommercial use, distribution, and reproduction in any medium, provided the original author(s) and source are credited.

\section{References}

Couwenberg J (2009) Emission factors for managed peat soils (organic soils, histosols) an analysis of IPCC default values. Report produced for the UN-FCCC meetings in Bonn, June 2009

de Haan H, van Liere L, Klapwijk SP, van Donk E (2006) The structure and function of fen lakes in relation to water table management in the Netherlands. Hydrobiologica 265:155-177

de Klein C, Novoa RSA, Ogle S, Smith KA, Rochette P, Wirth TC, McConkey BG, Mosier A, and Rypdal K (2006) Chapter 11: $\mathrm{N}_{2} \mathrm{O}$ emissions from managed soils, and $\mathrm{CO}_{2}$ emissions from Lime and Urea application. 2006 IPCC Guidelines for National Greenhouse Gas Inventories

Jones SK, Rees RM, Skiba UM, Ball BC (2005) Greenhouse gas emissions from a managed grassland. Glob Planet Change 47:201-211

Langeveld CA, Segers R, Dirks BOM, Van Den Pol-van Dasselaar A, Velthof GL, Hensen A (1997) Emissions of $\mathrm{CO}_{2}, \mathrm{CH}_{4}$ and $\mathrm{N}_{2} \mathrm{O}$ from pasture on drained peat soils in the Netherlands. Eur J Agron 7:35-42

Mosier AR, Duxbury JM, Freney JR, Heinemeyer O, Minami K (1996) Nitrous oxide emissions from agricultural fields: assessment, measurement and mitigation. Plant Soil 181: 95-108

Mosier AR, Duxbury JM, Freney JR, Heinemeyer O, Minami $\mathrm{K}$ (1998) Assessing and mitigating $\mathrm{N}_{2} \mathrm{O}$ emissions from agricultural soils. Clim Change 40:7-38

Parkin T (2008) Effect of sampling frequency on estimates of cumulative nitrous oxide emissions. J Environm Qual 37:1390-1395

Schils RLM, Verhagen A, Aarts HFM, Kuikman PJ, Sebek LBJ (2006) Effect of improved nitrogen management on greenhouse gas emissions from intensive dairy systems in the Netherlands. Glob Change Biology 12:382-391

Schrier-Uijl AP, Kroon PS, Leffelaar PA, van Huissteden JC, Berendse F, Veenendaal EM (2010) Methane emissions in two drained peat agro-ecosystems with high and low agricultural intensity. Plant Soil 329:509-520

Tiedje J, Sexstone A, Parkin T, Revsbech N, Shelton D (1984) Anaerobic processes in soil. Plant Soil 76:197-212

van Beek CL, Hummelink EWJ, Velthof GL, Oenema O (2004) Nitrogen losses through denitrification form an intensively managed grassland on peat soil. Biol Fertil Soils 39:329-336

van Beek CL, Pleijter M, van Groenigen JW, Velthof GL and Kuikman PJ (2009) Spatial and temporal variability of $\mathrm{N}_{2} \mathrm{O}$ emissions from a drained and grazed grassland, Paper presented in June 2009 at the 5th Non-Carbon Greenhouse Gas Conference (NCGG5) in Wageningen, The Netherlands. www.ncgg5.nl, Accessed on 13 September 2010 
van Beek CL, Pleijter M, Jacobs CMJ, Velthof GL, van Groenigen JW, Kuikman PJ (2010) Emissions of $\mathrm{N}_{2} \mathrm{O}$ from fertilized and grazed grassland on organic soil in relation to groundwater level. Nutr Cycl Agroecosyst 86:331-340

van der Hoek K, van Schijndel M, Kuikman PJ (2007) Direct and indirect nitrous oxide emissions from agricultural soils, 1990-2003 background document on the calculation method for the Dutch National Inventory report. RIVM, Bilthoven

van Groenigen JW, Zwart KB, Harris D, van Kessel C (2005a) Vertical gradients of delta $\mathrm{N}-15$ and delta $18 \mathrm{O}$ in soil atmospheric $\mathrm{N}_{2} \mathrm{O}$-temporal dynamics in a sandy soil. Rapid Commun Mass Spectrom 19:1289-1295

van Groenigen JW, Velthof GL, van der Bolt FJE, Vos A, Kuikman PJ (2005b) Seasonal variation in $\mathrm{N}_{2} \mathrm{O}$ emissions from urine patches: effects of urine concentration, soil compaction and dung. Plant Soil 273:15-27

Velthof G, Oenema O (1995) Nitrous oxide fluxes from grassland in the Netherlands: II effects of soil type, nitrogen fertilizer application and grazing. Eur J Soil Sci 46:541-549
Velthof GL, Koops JG, Duyzer JH, Oenema O (1996a) Prediction of nitrous oxide fluxes from managed grassland on peat soil using a simple empirical model. Neth J Agric Sci 44:339-356

Velthof GL, Brader AB, Oenema O (1996b) Seasonal variations in nitrous oxide losses from managed grasslands in The Netherlands. Plant Soil 181:263-274

Verhoeven JTA, Setter TL (2010) Agricultural use of wetlands: opportunities and limitations. Ann Bot 105:155-163

Williams DL, Ineson P, Coward PA (1999) Temporal variations in nitrous oxide fluxes from urine-affected grassland. Soil Biol Biochem 31:779-788

Wuebbles DJ (2009) Nitrous oxide: no laughing matter. Science 326:56-57

Zheng XH, Wang MX, Wang YS, Shen RX, Li J, Heyer J, Koegge M, Papen H, Jin JS, Li LT (2000) Mitigation options for methane, nitrous oxide and nitric oxide emissions from agricultural ecosystems. Adv Atmos Sci 17:83-92 